\title{
Service Quality, Satisfaction and Student Loyalty in Malaysian Private Education
}

\author{
Shaheen Mansori ${ }^{1}$, Anthony $\operatorname{Vaz}^{2} \&$ Zarina Mizam Mohd Ismail ${ }^{3}$ \\ ${ }^{1}$ School of Business, Berjaya University College of Hospitality, Kuala Lumpur, Malaysia \\ ${ }^{2}$ Faculty of Business, Communication and Law, Inti International University, Nilai, Malaysia \\ ${ }^{3}$ Institute of Educational Leadership, University Malaya, Kuala Lumpur, Malaysia \\ Correspondence: Shaheen Mansori, School of Business, Berjaya University College of Hospitality, Level 11 \\ West, Berjaya Times Square, No 1 Jalan Imbi, 55100 Kuala Lumpur, Malaysia. E-mail: \\ shaheen.mansori@gmail.com
}

Received: October 1, 2013 Accepted: January 1, 2014 Online Published: March 31, 2014

doi:10.5539/ass.v10n7p57 URL: http://dx.doi.org/10.5539/ass.v10n7p57

\begin{abstract}
The changing of the global demographic trends clearly suggests a growing demand for a quality higher education. In fact, several studies have been carried out in the past few years to explore the factors that have effects on the customer satisfaction and its consequences in various industries. In the same manner, this study also explores the five factors of service quality (SERVQUAL) and their relationship with the level of student satisfaction and their loyalty as well as the intervening role of satisfaction in the relationships between SERVQUAL factors and loyalty among undergraduate students.

The study used self-administered questionnaires to test the proposed model and data collected from 460 questionnaires were analysed. The questionnaires were distributed at various private universities and colleges in Malaysia based on convenience sampling. The results of this study are in accordance with prior studies in this field as SERVQUAL factors do influence the level of customers' satisfaction in the service industry. This study shows that the level of students overall satisfaction is mostly affected by tangibility. This finding indicates that the physical facility on the campus plays a major role in satisfying the students. The results also show that tangibility has the highest influence (directly and indirectly) on the students' intention to continue to a higher level of studies and/or spreading good word of mouth about the institution to their friends and the society. However, to generalize the results of this study, consideration should be made to the limitation of the number of the private institutions where the samples are collected. It is suggested that for further study, more samples should be taken from a larger number of institutions.
\end{abstract}

Keywords: SERVQUAL, satisfaction, word of mouth, post purchase behaviour, private education, loyalty

\section{Introduction}

The increase in student mobility in global higher education marks an important turning point in its landscape. The changing of the global demographic trends clearly suggests a growing demand for quality higher education. The significant changes in the infrastructure and the system of higher education in Asia (for example, Hong Kong, Singapore and Malaysia) have contributed to the exponential growth in supply and demand in the higher education industry in a very short period of time (Vaz \& Mansori, 2013).

Strategically geographically located, Malaysia is in the most progressive developing region in the world and has a strong base of foreign investments. It plays an active role in international organizations such as the Organization of Islamic Countries. The links to these types of organizations have created significant competitive advantages for the country to become an emerging force in the global higher education industry.

In 2011, the Malaysian Government became lenient in allowing more private higher education institutions to be a part of the local higher education industry by making an amendment to the Private Higher Education Act (1996). Furthermore, since 2009, it has been a part of the government's higher education policy to diversify into the local higher education market by allowing foreign based higher education institutions to establish their campuses locally. The Government also encourages collaboration among local and foreign higher education 
institutions. All of these changes in the education industry in recent years have created more options for students and make the competition more intense for higher education providers.

On the other hand, due to higher household income and the increase in Malaysia's gross domestic product (GDP) per capita, more students are able to enrol in higher education abroad. Additionally, private colleges and universities (PCU) have offered similar programs and thus make the implementation of a variety of strategies harder in order to create sustainable competitive advantage. Since product diversification has became difficult due to similar product launches by competitors, many PCUs focus on improving the quality of their services so that they can promote their institutions through high quality services.

Providing better education experience by offering higher and better quality service can increase students' satisfaction which can in return generate more revenue for PCUs. Previous researches have found that student satisfaction and the retention rate in higher education has a positive relationship and therefore the same assumptions can be applied in this study. High student satisfaction also can lead to an increment in intention to proceed to a higher level of studies in the same institution (Anderson, Fornell, \& Lehmann, 1994; Berthon, Ewing, \& Napoli, 2008)

Current literature has shown that customers, who are satisfied of company service, usually accept the higher price which can lead to increase the margin per customer. In addition, satisfied customers tend to support the company by spreading the good word of mouth (WOM) and increase the level of publicity of the company. As a result monitoring and reporting the customer satisfaction level is one of the tasks of marketing division of companies (Wangenheim \& Bayon, 2007; Wilson, 2002).

Several studies have tried to explore the cause of satisfaction/dissatisfaction and its effects on companies' profitability in different sectors of industries. However, there is not many literature are found on private education industry and more specifically in Malaysian PUCs. Unlike other industries, the impact of the services in education is different because the level of its quality can influence the entire career of students. Moreover in education, the cost to switch universities or even programmes, is very high due to the diversified curriculum. Thus, students who are dissatisfied have no choice most of the time but to proceed with their studies at the institution despite the quality of the services provided. Under these circumstances, students may use social media and other mediums of communication to express their dissatisfaction and this would possibly tarnish the institution's reputation. Therefore, private education institution policy makers should be aware of the factors that can influence the level of the students' satisfaction and realize how it can affect the institution.

To address this issue and to find the answer for this dilemma, the study intends to explore the relationship between reliability, tangibility, responsiveness, empathy and assurance factors which are known as SERVQUAL with the level of student satisfaction and student loyalty as well as the intervening role of student satisfaction in the relationships between SERVQUAL factors and student loyalty among undergraduate students.

\section{Literature Review}

\subsection{Concept of Service Quality}

The realization of the importance of the quality in the service industry has begun since the 1980s when supply exceeded demand significantly in many developed markets. However, the noteworthy move toward implementation and the study of service quality only kicked off in 1990s when companies started to focus on quality of service as the main contributor in satisfaction / dissatisfaction (Chen \& Aritejo, 2008).

Parasuraman et al., (1988) begun carrying out service quality studies in the 1980 s by researching different sectors in the service industry. In their studies, a variety of aspects were explored which can be considered as factors that can affect the service quality based on customers point of view (Parasuraman et al., 1988). Initially they included eleven factors into their exploratory study which included reliability, responsiveness, customization, credibility, competence, accessibility, courtesy, security, communication, tangibility and understanding or knowing the customer. However, after analyzing the results, they only published assurance, empathy, responsiveness, reliability, and tangibles as factors that can influence the service quality. They include these factors in SERVQUAL which is a measurement instrument for measuring the quality in services (Parasuraman, et al., 1988). Based on the tests done on these five dimensions of SERVQUAL in many industries indicate that they are reliable and valid (Brysland \& Curry, 2001; Kassim \& Abdullah, 2010; Lee, Kim, \& Ahn, 2011; Naik, Krishna, \& Gantasala, 2010; Sohail, 2003; Sohail \& Shaikh, 2004).

Customers' trust and confidence in employees' knowledge and courtesy of an organization shows that they have confidence and assurance pertaining to the service outcome (Yap, Wong, Loh, \& Bak, 2010). Assurances given by the company to their customers (students in the case of education) means that "We are sure of what we say 
and do" (Vaz \& Mansori, 2013). However, lack of confidence in the institution can occur when employees fail to provide or update the information needed by customers and thus can reduce the level of assurance which consequently leads to dissatisfaction. To test this issue from students' perspectives the below hypothesis is developed:

H1: There is a significant relationship between assurance and student satisfaction.

Empathy can be defined as a deep caring and understanding of the customers' feelings, situations and motives. It evokes the desire to offer help that customers need by showing sympathy and compassion that match customers' thinking, feeling or emotions (Hodges \& Klein, 2001; Kassim \& Abdullah, 2010). Thus, the show of empathy by the institutions through their services to the customers convey the message that "We feel for you". This factor is considerably important in the education industry since the main group of customers in institutions are young people who can be highly emotional due to personal or study problems. Therefore, the hypothesis below is developed to test the relationship between empathy and student satisfaction:

\section{$\mathrm{H} 2$ : There is a significant relationship between empathy and student satisfaction}

Responsiveness refers the level of the promptness in the staffs' response to the customers' enquiries (Lee, et al., 2011) by showing that "We will get it done now". The relationship between students and their institution may start from the time of enrolment until their convocation, and it may go on beyond that through alumni activities. Therefore, prompt actions which are taken following the student enquiries and complaints can be a determinant factor in determining the level of student satisfaction. Hence, the hypothesis below is developed to test this phenomenon:

H3: There is a significant relationship between responsiveness and student satisfaction.

Reliability is related to the accuracy and dependability of the services provided (Kassim \& Abdullah, 2010). Reliability shows the company meant it when it says "We deliver what we promise". Reliability in the education industry refers to the promises which are made by different levels of authority such as marketing teams, faculty members, regarding the program and teaching faculty. Any misleading information or oversell promises made by the marketing team can create expectations which are beyond the university's capacity to deliver which could later lead to students' dissatisfaction. Therefore, to test the significant influence of this factor on student satisfaction the hypothesis below is developed:

\section{$\mathrm{H} 4$ : There is a significant relationship between reliability and student satisfaction}

Tangibility of service addresses all companies hardware such as building, facilities, communication channels (e.g., notice boards) and even the staff appearance (Naik et al., 2010). In other words, the company is able to convey a message that "We can show it to you" by providing the facilities the customers need. The availability of facilities is one of the major factors for students to select a particular institution (Dutta \& Dutta, 2009). Therefore, the quality of service related to the provided facilities is very important in determining whether the students will be satisfied or dissatisfied with their chosen institution. As a result, to test this issue using empirical evidence the hypothesis below is developed;

H5: There is a significant relationship between tangibility and student satisfaction

\subsection{Relationship between Service Quality, Customer Satisfaction and Loyalty}

Satisfaction/dissatisfaction is the outcome of comparison between customer's perception about the quality or attribute of product/service and the deliverance of promise by company (Oliver, 2009). If the deliverance of the company meets or exceeds the customer's expectation then the customer will be either satisfied or even delighted. However, if the company fails to meet the customer expectation, which might be created by overselling by the sales people, the gap between customer expectation and the quality of the actual provided services can cause dissatisfaction. Since switching course can be costly for students in the education industry, even when they are dissatisfied of the institution's services they have no choice but to stay with the current institution. However, the possibility of the spreading bad word of mouth about the institution is high and this can tarnish the reputation of the institution.

Customer loyalty can be established in many ways such as support towards a certain organization by continue patronizing a certain provider and this leads to increment in the frequency of their purchases (Rowley, 2005; Wilkins, Merrilees, \& Herington, 2009). According to Olorunniwo et al., (2006), customers who are loyal have an impact on the profitability and overall success of the organization in two distinctive ways. First, through continuous liaison with the education institution by furthering their studies at higher levels in the same institution. This can reduce the attrition rate of students and increase the profit per student by lowering the cost of marketing 
and advertising and thus reduce the organization's operating costs. Secondly, loyal customers tend to have a higher level of repurchase and recommendation intentions (Al-Rousan \& Mohamed, 2010). In other words, satisfied and loyal students are more likely to spread favourable comments and recommend the institution to others. It is very importance in the education industry since recruiting new students is very costly. It is also very difficult to carry out conventional marketing approaches (for example, advertising and promotional activities) because the market place for education industry has became global (Vaz \& Mansori, 2013).

However, despite the high importance of loyalty and student satisfaction in the education industry, not many studies investigate the factors which can influence these issues. Moreover, most of the current studies have used only quantitative approaches which cannot give an in depth picture of this phenomena (Vaz \& Mansori, 2013). Hence, to study the relationship between satisfaction and loyalty in the education industry from the students' perspective the hypothesis below is developed:

H6: There is a significant relationship between student satisfaction and word of mouth.

H7: There is a significant relationship between student satisfaction and student's intention to continue a relationship with an institution.

\subsection{Theoretical Model of Study}

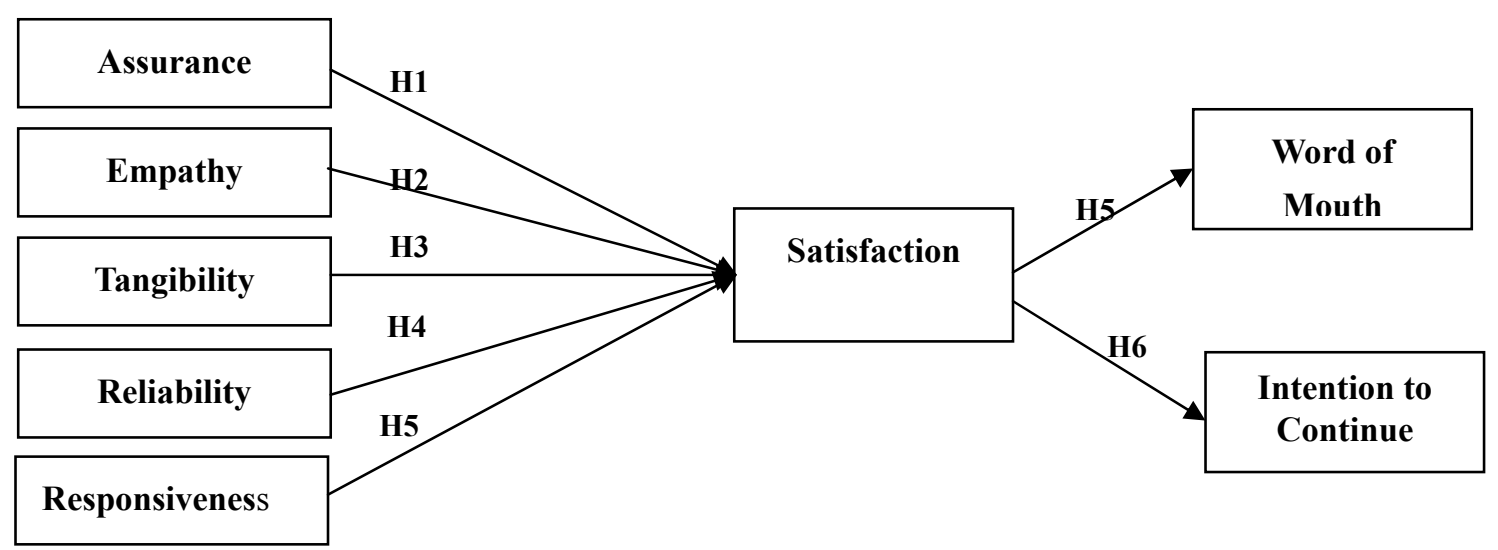

\section{Data and Results Analysis}

To test the hypotheses of this study, 460 questionnaires were distributed using convenience sampling among students in different faculties in three different PUCs in Malaysia. The questionnaire has four parts. The first part, using the SERVQUAL measurements measures the level of perception toward service quality. In the second part, students' overall satisfaction is measured by five questions. Section three of the questionnaire is designed to collect demographic information about the students. Lastly, the questionnaire contains an open ended question, "My University is ..." which gives an opportunity to the participants to express their perceptions about their institution or voice out an issue that they may have.

After going through all the collected questionnaires, 29 questionnaires were excluded from the analysis due to missing data and/or showing some trend in the responses, for example, rating all responses as either 5 or 1 . Demographic information of participants is presented in Table 1. These results indicate that the majority of participants are degree students follows by diploma and degree transfer students (see Table1).

Table 1. Demographic factors

\begin{tabular}{|c|c|c|c|c|c|c|c|}
\hline & & Frequency & Percent & & & Frequency & Percent \\
\hline \multirow{2}{*}{ Gender } & Male & 216 & 50.4 & \multirow{4}{*}{ Level } & DEGREE & 249 & 58 \\
\hline & Female & 215 & 49.6 & & DIPLOMA & 78 & 18.1 \\
\hline \multirow{2}{*}{ Nationality } & LOCAL & 356 & 82 & & DEGREE TRANSFER & 66 & 16.9 \\
\hline & INTERNATIONAL & 75 & 18 & & PRE-UNIVESITY & 38 & 7.0 \\
\hline
\end{tabular}


The validity test is done to test of validity of the employed measurement. Table 2 shows the results of the validity test which indicates that the current instrument is valid and all variables meet the minimum thresholds ( $p$-value $<.001$ and $\mathrm{KMO}>.70$ ). Furthermore, reliability test's results indicate that all constructs are acceptable since Cronbach Alphas (more than .7), average variance expected (AVE > .4) and the composite reliability $(\mathrm{CR}>$.7) of variables have met the minimum requirement (Okazaki, 2011).

Table 2. Validity and reliability

\begin{tabular}{lllll}
\hline Variable & KMO/Sig & Cronbach Alphas & AVE & CR \\
\hline Tangibility & $.80 / .001$ & .74 & .40 & .82 \\
Reliability & $.84 / .001$ & .84 & .56 & .88 \\
Responsiveness & $.72 / .001$ & .77 & .53 & .88 \\
Assurance & $.75 / .001$ & .72 & .58 & .83 \\
Empathy & $.71 / .001$ & .77 & .68 & .86 \\
Satisfaction & $.79 / .001$ & .83 & .66 & .89 \\
Word of Mouth & $.70 / .001$ & .84 & .86 & .92 \\
Intention for Continue & $.73 / .001$ & .85 & .84 & .94 \\
\hline
\end{tabular}

The results of SEM show that Chi-square $=103.134 / \mathrm{D}=1$. GFI $=.93$, CFI $=.931$, NFI .93, IFI $=.932$ and RMSEA $=.29$. The results for model fit show that all indices are perfectly good except RMSEA (Hair, Black, Babin, \& Anderson, 2010). In the case of RMSEA, studies show that this index is sensitive to the number of variables and has a tendency to suggest better model fit when the number of variables is high but CFI and TFI would suggest a worse fit index as the number of the observed variables increase (Breivik \& Olsson, 2001; Fan \& Sivo, 2007).

The results in Table 3 show that $\mathrm{H} 2$ (p-value $=.0001 \beta=.187), \mathrm{H} 3$ (p-value $=.007, \beta=.126$ ), and $\mathrm{H} 5$ $(p$-value $=.0001, \beta=.425)$, are supported as all $p$-values are less than .05 . However, H1 and H4 are rejected because their $p$-values are more than .05 .The results also indicate that the factor which has the highest influence on student satisfaction is tangibility followed by empathy and responsiveness. Moreover, current results of H6 ( $\mathrm{p}$-value $=.0001, \beta=.497)$ and $\mathrm{H} 7$ ( $\mathrm{p}$-value $=.0001, \beta=.37$ ) show that student satisfaction has a positive and significant relationship with word of mouth and student intention to continue their studies with the same institution.

Table 3. Estimates of regression weights

\begin{tabular}{lllllll}
\hline & & & Estimate & S.E. & C.R. & P \\
\hline Satisfaction & $\leftarrow$ & Responsiveness & .126 & .046 & 2.718 & .007 \\
Satisfaction & $\leftarrow$ & Empathy & .187 & .045 & 4.191 & .001 \\
Satisfaction & $\leftarrow$ & Assurance & .011 & .048 & .237 & .813 \\
Satisfaction & $\leftarrow$ & Reliability & -.035 & .047 & -.753 & .451 \\
Satisfaction & $\leftarrow$ & Tangibility & .425 & .053 & 7.979 & .001 \\
Word of Mouth & $\leftarrow$ & Satisfaction & .497 & .066 & 7.478 & .001 \\
Intention & $\leftarrow$ & Satisfaction & .366 & .095 & 3.861 & .001 \\
\hline
\end{tabular}

The results from Table 3 also reveal that there should be other types of relationships between the variables in the model rather than only direct relationship. Therefore, to test the mediation effect of student satisfaction on the relationship between SERVQUAL dimensions and post purchase behaviour among students, the model was run without the presence of the intervening variable (satisfaction). 
Table 4. Direct relationship between SERVQUAL dimensions and post purchase behaviour factors without the presence of intervening variable (satisfaction)

\begin{tabular}{lllllll}
\hline & & & Estimate & S.E. & C.R. & P \\
\hline WOM & $\leftarrow$ & Assurance & .002 & .067 & .037 & .971 \\
WOM & $\leftarrow$ & Empathy & .241 & .062 & 3.890 & .001 \\
WOM & $\leftarrow$ & Responsiveness & .176 & .065 & 2.718 & .007 \\
WOM & $\leftarrow$ & Reliability & .142 & .065 & 2.183 & .029 \\
WOM & $\leftarrow$ & Tangibility & .305 & .074 & 4.107 & .001 \\
Intention & $\leftarrow$ & Assurance & .166 & .090 & 1.840 & .066 \\
Intention & $\leftarrow$ & Empathy & .195 & .084 & 2.315 & .021 \\
Intention & $\leftarrow$ & Responsiveness & .014 & .088 & .160 & .873 \\
Intention & $\leftarrow$ & Reliability & .073 & .088 & .821 & .412 \\
Intention & $\leftarrow$ & Tangibility & .317 & .101 & 3.147 & .002 \\
\hline
\end{tabular}

The results in Table 4 show that the first assumption of Baron and Kenny (1986) is met since empathy, responsiveness and tangibility are directly related with word of mouth. In addition to that, the results show a significant relationship between empathy, tangibility with intention ( $\mathrm{p}$-value $<.05)$. However the first assumption of Baron and Kenny (1986) does not exist for other relationships as the relationships between assurance and word of mouth, assurance and intention, responsiveness and intention and reliability and intention are not significant ( $\mathrm{p}$-value $>.05$ ).

Secondly, the mediator variable is added to the model and the bootstrap test was run for 10,000 times. The results in Table 6 show that student satisfaction has a significant mediation role in the relationship between empathy, responsiveness and tangibility and word of mouth (Total Effects p-values $<.05$ ). In addition, as in the presence of student satisfaction, the direct relationship of this factor and word of mouth is insignificant (see Table 6). Therefore it can be concluded that student satisfaction can fully mediate the relationship between empathy, responsiveness and tangibility and word of mouth (Direct effect p-value> .05).

Table 5. Standardized total effects

\begin{tabular}{lllllll}
\hline & Tangibility & Reliability & Assurance & Empathy & Responsiveness & Satisfaction \\
\hline Satisfaction & .422 & .043 & .014 & .224 & .141 & .000 \\
Two Tailed & .0001 & .446 & .806 & .0001 & .011 & $\ldots$ \\
Significance & & & & & & \\
Intention & .197 & .056 & .125 & .146 & .010 & .229 \\
Two Tailed & .004 & .427 & .117 & .044 & .884 & .000 \\
Significance & & & & & & .376 \\
WOM & .229 & .132 & -.002 & .219 & .149 & .000 \\
Two Tailed & .001 & .06 & .994 & .002 & .011 & \\
Significance & & & & & & \\
\hline
\end{tabular}

Moreover, the results show that student satisfaction fully mediate the relationship between tangibility and empathy with intention since the p-value of the direct relationship is more than .05 (see Table 5 and Table 6). 
Table 6. Standardized direct effects

\begin{tabular}{lllllll}
\hline & Tangibility & Reliability & Assurance & Empathy & Responsiveness & Satisfaction \\
\hline Satisfaction & .422 & -.043 & .014 & .224 & .141 & .000 \\
Two Tailed & .000 & .446 & .806 & .000 & .011 & $\ldots$ \\
Significance & & & & & & \\
Intention & .101 & .066 & .122 & .095 & -.042 & .229 \\
Two Tailed & .138 & .349 & .123 & .193 & .508 & .000 \\
Significance & & & & & & .376 \\
Word of Mouth & .071 & .148 & .007 & .135 & .096 & .0001 \\
Two Tailed & .138 & .349 & .123 & .193 & .508 & \\
Significance & & & & & & \\
\hline
\end{tabular}

Overall the results reveal that tangibility followed by empathy has the highest effect on students' intention when they are considered to enrol in a particular institution for higher education in the future $\left(\beta_{\text {Tangibility }}=.197 / \mathrm{p}\right.$-value $=.0001, \beta_{\text {Empathy }}=.146 / \mathrm{p}$-value $\left.=.0001\right)$. Furthermore, the results also show that the highest impact on students' positive word of month for an institution is tangibility followed by empathy and responsiveness $\left(\beta_{\text {Tangibility }}=.229 / \mathrm{p}\right.$-value $=.001, \quad \beta_{\text {Empathy }}=.219 / \mathrm{p}$-value $=.0001$ and $\beta_{\text {Responsiveness }}=.149 /$ $\mathrm{p}$-value $=.0001)($ see Table 5,6 and7 $)$.

Table7. Standardized indirect effects

\begin{tabular}{lrrrrrr}
\hline & Tangibility & Reliability & Assurance & Empathy & Responsiveness & Satisfaction \\
\hline Satisfaction & .000 & .000 & .000 & .000 & .000 & .000 \\
Two Tailed & $\ldots$ & $\ldots$ & $\ldots$ & $\ldots$ & $\ldots$ & $\ldots$ \\
Significance &.. & .010 & .003 & .051 & .032 & .000 \\
Intention & .097 & .446 & .806 & .000 & .011 & $\ldots$ \\
Two Tailed & .000 & .016 & .005 & .084 & .053 & .000 \\
Significance & .159 & .446 & .806 & .000 & .011 & $\ldots$ \\
WOM & .000 & & & & & \\
Two Tailed & & &
\end{tabular}

\section{Discussion and Analysis of Projection Question}

The result of this study supports previous reliability and validity studies using SERVQUAL in Malaysia education industry as the entire index for reliability and validity are met or exceed the minimum threshold which confirm the robustness of this measurement in different markets. Moreover, the results of this study are in accordance with prior studies in this field as SERVQUAL factors may influence the level of customers' satisfaction in the service industry. This study shows that tangibility has the highest impact on students overall satisfaction level which supports previous research findings (Dutta \& Dutta, 2009). This finding indicates that the physical facilities on the campus (for example, computer labs, library, classrooms etc.) has a major impact on student satisfaction. The results also show that tangibility has the highest influence (directly and indirectly) on the students' intention to further their study at a higher level and they would also spread good word of mouth about the institution to their friends and the society.

This finding is also supported by the answers given in the last question. The majority of comments about the university highly focus on the quality of physical infrastructures such as classrooms, security, library, sport facilities, internet service, hostel and student canteens. For example: 
- "Classrooms are very dirty and ceiling got leakage"

- "Security system in campus is not good enough ..... I feel insecure sometimes."

- "Some computers in the library do not function even".

The second factor that can influence the overall level of students' satisfaction in an institution is empathy or the effort made by the staffs to understand the students' needs and emotions. (Kassim \& Abdullah, 2010). Empathy plays an important role in determining the students' intention to either recommend the institution to their friends and relatives or in their decision to further their studies to the higher levels of education. The findings show that personalize relationship with the institution's staffs is really important to the students especially during the time when the students may face some difficulties in certain situations such as dealing with their curriculum and other personal issues. The complaints pertaining to the staff's behaviour and their sense of empathy are also reflected in the open ended questions. Below are a couple of samples of students' response:

- "The guards aren't fair to every student, showing fierce face."

- "The staff shows bad manners sometimes towards students, not courteous at all. They are quite rude sometimes."

Essentially, education institutions should provide soft skills training for their staffs so that they are able to help and provide better services to the students in their hour of need. The staffs also need to improve their communication skills in order to have a better relationship with the students and indirectly improve the level of satisfaction among their students.

The third factor that can influence the overall students' satisfaction significantly is the staff's responsiveness in providing the services (Lee et al., 2011). This finding indicates that students look for fast and prompt responses from the institution's staffs and any delay in addressing their enquiry can cause dissatisfaction. The following is a couple of examples of the perspectives that the students highlight from the projection question:

- "Slow respond from international office staffs"

- "Lecturers should keep more attention to each student, meaning to know the improvement of students.

The above responses show that it is important for an education institution to prepare clear standard operations procedures (SOPs) for different processes and issues to guide the staffs in addressing the students or their parents' enquiry. In addition, it is important that staffs show them courtesy and thus, should be approachable and accessible to students at the time of their need. This factor is important since it can directly and indirectly influence the level of commitment from the students to share their good experience and therefore give a positive recommendation to their friends and the relatives.

Despite the significant relationship between the above three factors of SERVQUAL and overall satisfaction, reliability and assurance did not show any significant impact on overall satisfaction. One of the possibilities for this outcome can be due to the nature of the education industry since it is highly regulated in Malaysia. In order to launch new academic programmes, all institutions are required to submit their application to the Malaysian Qualifications Agency (MQA), a regulatory body which assesses the quality of programmes and institutions. Upon MQA's approval, the institutions will have permission to advertise and implement their programmes. Therefore, it is possible that students will consider it as an assurance and reliability of the programme in an institution as a standard that should be in place by default.

As a conclusion, this study shows that students' level of satisfaction with the private education offered by the PUCs reflects the quality of the programme offers and the services provided by the PUCs. Moreover, the factors studied in this study do clearly illustrate the relationship between service quality, satisfaction and student loyalty which can be used in the future study which could have done with a wider scope and broader geographical area. It is also hoped that this study may able to provide some insights for private education industry especially in Malaysia.

\section{References}

Al-Rousan, M. R., \& Mohamed, B. (2010). Customer loyalty and the impacts of service quality: The case of five star hotels in Jordan. International Journal of Business, Economics, Finance and Management Sciences, 2(3), 886-892.

Anderson, E. W., Fornell, C., \& Lehmann, D. R. (1994). Customer satisfaction, market share, and profitability: findings from Sweden. The Journal of Marketing, 58(3), 53-66. http://dx.doi.org/10.2307/1252310

Baron, R. M., \& Kenny, D. A. (1986). The moderator-mediator variable distinction in social psychological 
research: Conceptual, strategic, and statistical considerations. Journal of personality and social psychology, 51(6), 1173. http://dx.doi.org/10.1037/0022-3514.51.6.1173

Berthon, P., Ewing, M. T., \& Napoli, J. (2008). Brand Management in Small to Medium-Sized Enterprises. Journal of Small Business Management, 46(1), 27-45. http://dx.doi.org/10.1111/j.1540-627X.2007.00229.x

Breivik, E., \& Olsson, U. H. (2001). Adding variables to improve fit: The effect of model size on fit assessment in LISREL. Structural equation modeling: Present and future. A Festschrift in honor of Karl JÃ $\llbracket$ reskog, 169-194.

Brysland, A., \& Curry, A. (2001). Service improvements in public services using SERVQUAL. Managing Service Quality, 11(6), 389-401. http://dx.doi.org/10.1108/09604520110410601

Chen, J. V., \& Aritejo, B. A. (2008). Service quality and customer satisfaction measurement of mobile value-added services: A conceptual review. International Journal of Mobile Communications, 6(2), 165-176 http://dx.doi.org/10.1504/IJMC.2008.016575

Dutta, K., \& Dutta, A. (2009). Customer expectations and perceptions across the Indian banking industry and the resultant financial implications. Journal of Services Research, 9(1), 32-49.

Fan, X., \& Sivo, S. A. (2007). Sensitivity of fit indices to model misspecification and model types. Multivariate Behavioral Research, 42(3), 509-529. http://dx.doi.org/10.1080/00273170701382864

Hair, J., Black, W., Babin, B., \& Anderson, R. (2010). Multivariate data analysis: A global perspective. Pearson Education.

Hodges, S. D., \& Klein, K. J. (2001). Regulating the costs of empathy: the price of being human. The Journal of socio-economics, 30(5), 437-452. http://dx.doi.org/10.1016/S1053-5357(01)00112-3

Kassim, N., \& Abdullah, N. A. (2010). The effect of perceived service quality dimensions on customer satisfaction, trust, and loyalty in e-commerce settings: A cross cultural analysis. Asia Pacific Journal of Marketing and Logistics, 22(3), 351-371. http://dx.doi.org/10.1108/13555851011062269

Lee, J., Kim, H. J., \& Ahn, M. J. (2011). The willingness of e-Government service adoption by business users: The role of offline service quality and trust in technology. Government Information Quarterly, 28(2), 222-230. http://dx.doi.org/10.1016/j.giq.2010.07.007

Naik, C., Krishna, G. S. B., \& Gantasala, V. (2010). Service quality (SERVQUAL) and its effect on customer satisfaction in retailing. European Journal of Social Sciences, 16(2), 231-243.

Okazaki, S. (2011). Advances in Advertising Research (Vol. 2): Breaking New Ground in Theory and Practice. Gabler Verlag. http://dx.doi.org/10.1007/978-3-8349-6854-8

Oliver, R. L. (2009). Satisfaction: A behavioral perspective on the consumer. ME Sharpe Inc.

Olorunniwo, F., Hsu, M. K., \& Udo, G. J. (2006). Service quality, customer satisfaction, and behavioral intentions in the service factory. Journal of Services Marketing, 20(1), 59-72. http://dx.doi.org/10.1108/08876040610646581

Parasuraman, A., Zeithaml, V. A., \& Berry, L. L. (1988). SERVQUAL: A Multiple-Item Scale for Measuring Customer Expectations of Service. Journal of Retailing, 64(1), 12-40.

Rowley, J. (2005). The four Cs of customer loyalty. Marketing Intelligence \& Planning, 23(6), 574-581. http://dx.doi.org/10.1108/02634500510624138

Sohail, M. S. (2003). Service quality in hospitals: more favourable than you might think. Managing Service Quality, 13(3), 197-206. http://dx.doi.org/10.1108/09604520310476463

Sohail, M. S., \& Shaikh, N. M. (2004). Quest for excellence in business education: A study of student impressions of service quality. International Journal of Educational Management, 18(1), 58-65. http://dx.doi.org/10.1108/09513540410512163

Vaz, A., \& Mansori, S. (2013). Malaysian Private Education Quality: Application of SERVQUAL Model. International Education Studies, 6(4), 164. http://dx.doi.org/10.5539/ies.v6n4p164

Wangenheim, F., \& Bayon, T. (2007). The chain from customer satisfaction via word-of-mouth referrals to new customer acquisition. Journal of the Academy of Marketing Science, 35(2), 233-249. http://dx.doi.org/10.1007/s11747-007-0037-1

Wilkins, H., Merrilees, B., \& Herington, C. (2009). The determinants of loyalty in hotels. Journal of Hospitality 
Marketing \& Management, 19(1), 1-21. http://dx.doi.org/10.1080/19368620903327626

Wilson, A. M. (2002). Attitudes towards customer satisfaction measurment in the retail sector. International Journal of Market Research, 44(2), 213-222.

Yap, K. B., Wong, D. H., Loh, C., \& Bak, R. (2010). Offline and online banking-where to draw the line when building trust in e-banking? International Journal of Bank Marketing, 28(1), 27-46. http://dx.doi.org/10.1108/02652321011013571

\section{Copyrights}

Copyright for this article is retained by the author(s), with first publication rights granted to the journal.

This is an open-access article distributed under the terms and conditions of the Creative Commons Attribution license (http://creativecommons.org/licenses/by/3.0/). 